\title{
Studies on the Group F Antigen of Lactobacilli: Detection of Antibodies by Haemagglutination
}

\author{
By MERIL YN J. HEWETT AND K. W. KNOX \\ Institute of Dental Research, United Dental Hospital, Surry Hills, \\ N.S.W. 20ro, Australia \\ AND A. J. WICKEN \\ School of Microbiology, University of New South Wales, P.O. Box I, \\ Kensington, N.S.W. 2033, Australia
}

(Accepted for publication II November I969)

SUMMARY

Teichoic acid-lipid complexes from Lactobacillus fermenti NCTC 6991 absorb to normal sheep red blood cells. Sensitized cells are agglutinated by specific antisera, the titres of representative sera being 1600 to 3200 . Lipidfree teichoic acid does not sensitize red blood cells but inhibits haemagglutination. Haemagglutination is inhibited completely by intact cells of L. fermenti NCTC $699 \mathrm{I}$, but only partially by other strains of L. fermenti. Strains of lactobacilli of other serological groups absorb a variable proportion of antibody. The group F antigen is a membrane teichoic acid and the significance of the absorption by intact bacterial cells is discussed.

\section{INTRODUCTION}

The serological classification of group $\mathrm{F}$ lactobacilli has been shown to depend on a glycerol teichoic acid associated with the cell membrane and having glucose and galactose substituents: by using a mild phenol extraction procedure the isolated product contained both glycolipid and phospholipid, and retained its antigenicity (Knox, Hewett \& Wicken, I970; Wicken \& Knox, 1970).

The presence of lipid as an integral component of the antigen, referred to as lipoteichoic acid, suggested the application of passive haemagglutination as a procedure for the detection of antigen and the corresponding antibodies. Lipid-free polysaccharides do not generally absorb to red blood cells, and Hämmerling \& Westphal (1967) have suggested that absorption depends on the formation of hydrophobic bonds between the lipid component of the erythrocyte membrane and the lipid-polysaccharide complex. Such a requirement would account for reports of the failure of preparations of purified teichoic acid to absorb to erythrocytes (Hofstad, I965; Yoshida \& Ekstedt, 1968). It has now been shown that lipoteichoic acid from Lactobacillus fermenti NCTC 699I will absorb to normal sheep red blood cells, whereas the corresponding lipid-free product does not. The reaction can be used as a sensitive means of detecting antibodies to L. fermenti.

METHODS

Organisms. Cultures of Lactobacillus of serological groups B, C and F were obtained from the sources previously described (Knox et al. 1970). Cultures of organisms of 
groups A, D and E were kindly supplied by Dr M. E. Sharpe, National Institute for Research in Dairying, Reading, England, and corresponded to those used by Sharpe, Davison \& Baddiley (1964). The cultures listed under serological groups were: group A, L. helveticus NCIB 8025; group B, L. casei NIRD H83I; group C, L. casei NIRD R094 and strain NCTC 6375; group D, L. plantarum NCIB 7220; group E, L. bulgaricus $\mathrm{B} 9$ and L. lactis NCIB 7278; and group F, L. fermenti NCTC 699I and laboratory strains 77 and I26. Organisms were grown under the conditions described by Sharpe (I955).

Isolation of cell components. Cell wall from Lactobacillus fermenti NCTC 699I was prepared as described previously (Knox \& Holmwood, I968). A similar procedure was used for obtaining wall from $L$. plantarum NCIB 7220 . Teichoic acid was isolated from disrupted cells of $L$. fermenti NCTC 6991 (Wicken \& Knox, I970) and the same fractions used as in previous serological studies (Knox et al. 1970). Phenol-extracted teichoic acid is designated P-teichoic acid; extraction with trichloracetic acid yielded a high molecular weight fraction, HT-teichoic acid, and a low molecular weight fraction LT-teichoic acid. To remove fatty acids from HT-teichoic acid a solution $(500 \mu \mathrm{g}$. $)$ $0.5 \mathrm{ml}$.) was mixed with one volume aqueous ammonia (sp.gr. 0.88 ) and left for $\mathrm{I} 6 \mathrm{hr}$ at room temperature (Knox et al. 1970). Partial removal of fatty acids was achieved by treating with $15 \%(\mathrm{v} / \mathrm{v})$ aqueous ammonia, and leaving for $30 \mathrm{~min}$. at room temperature (cf. Jackson \& Moskowitz, I966).

Preparation of antisera. Antisera to whole cells were obtained by intravenous injection of a cell suspension, and to teichoic acids by injection in Freund's adjuvant (Knox et al. 1970). Antisera used in the present investigation were obtained as follows: antiserum 99/3, three series of intravenous injections of Lactobacillus fermenti NCTC 699I ; antisera I32 and I48, injection of P-teichoic acid with incomplete and complete Freund's adjuvant respectively; antisera 150 and I5I, injection in complete adjuvant of HT-teichoic acid and LT-teichoic acid respectively.

Detection of teichoic acid in extracts of disintegrated cells. Suspensions of Lactobacillus fermenti NCTC 699I (28 mg. $/ \mathrm{ml}$.) were disintegrated for 5, I0, 20 and $35 \mathrm{~min}$. (Shockman, Kolb \& Toennies, I 957). After removal of cell wall by centrifugation at I2,000 $\mathrm{g}$ for $20 \mathrm{~min}$. the supernatant fraction from each period of disintegration was centrifuged further for $90 \mathrm{~min}$. at $100,000 \mathrm{~g}$. The supernatant solution was removed and the pellet reconstituted in $0.85 \%(\mathrm{w} / \mathrm{v}) \mathrm{NaCl}$ and neutralized. Tenfold dilutions of the residue and supernatant fractions were prepared in $0.066 \mathrm{M}$ phosphate buffer, $\mathrm{pH} \mathrm{7.4}$, containing $0.85 \% \mathrm{NaCl}$ and 0.05 to $0.2 \mathrm{ml}$. of solution examined for reactivity with antiserum I48 (0. I ml.) by the quantitative precipitin method (Heidelberger \& MacPherson, 1943; Knox et al. 1970). By comparison with P-teichoic acid standards, the teichoic acid content of the extracts was estimated. To follow the release of cell components, the extinction of the whole extract (diluted 20-fold) was read at $260 \mathrm{~m} \mu$.

Determination of haemagglutination titre. Sheep red blood cells were washed five times with $0.85 \% \mathrm{NaCl}$. Packed cells $(0.2 \mathrm{ml}$.) were mixed with a solution of teichoic acid in $0.85 \% \mathrm{NaCl}$ to give a final $2 \%(\mathrm{v} / \mathrm{v})$ suspension of red blood cells and a teichoic acid concentration of 2.5 to $50 \mu \mathrm{g}$. $/ \mathrm{ml}$. Controls containing no added teichoic acid were also prepared, and the mixtures rolled at $37^{\circ}$ for $30 \mathrm{~min}$, followed by standing at 2 to $4^{\circ}$ for $\mathrm{I} 6 \mathrm{hr}$. The erythrocytes were washed three times with $0.85 \% \mathrm{NaCl}$ and finally suspended to $2 \%(\mathrm{v} / \mathrm{v})$ in $0.85 \% \mathrm{NaCl}$. In order to remove naturally occurring haemagglutinins, antisera were absorbed with $10 \%(\mathrm{v} / \mathrm{v})$ normal sheep red blood cells, and complement was destroyed by heating the absorbed sera at $56^{\circ}$ for $30 \mathrm{~min}$. Serial 
dilutions of serum were prepared in $0.85 \% \mathrm{NaCl}$ containing normal absorbed rabbit serum $(0 \cdot 2 / 100 \mathrm{ml}$.). The addition of normal serum prevented non-specific lysis and stabilized the haemagglutinated cells (Mrs B. Humphrey, personal communication). To each serial dilution of antiserum (0.1 or $0.2 \mathrm{ml}$.) was added an equal volume of sensitized erythrocytes. The reactants were mixed and incubated for $3 \mathrm{hr}$ at $37^{\circ}$. The reciprocal of the greatest dilution showing agglutination on macroscopic inspection was recorded as the end-point or titre.

Inhibition of haemagglutination by teichoic acid preparations was examined by adding inhibitor (10 $\mu \mathrm{g}$. in $10 \mu \mathrm{l}$ ) to each serial dilution of antiserum. After $\mathrm{I} \mathrm{hr}$ at $37^{\circ}$, one volume of sensitized cells was added and the above procedure followed.

\section{RESULTS}

\section{Ability of teichoic acid preparations to sensitize erythrocytes}

Preliminary experiments using $50 \mu \mathrm{g}$. teichoic acid $/ \mathrm{ml}$. indicated that P- and HTteichoic acid absorbed to normal sheep red blood cells but that there was no detectable absorption of LT-teichoic acid; subsequent studies indicated that $10 \mu \mathrm{g}$. teichoic acid $/ \mathrm{ml}$. was sufficient for sensitization. The titres of active sera only vary from 1600 to 3200 (Table I) whereas the antibody content by the precipitin method showed a

\section{Table I. Haemagglutination titres of antisera}

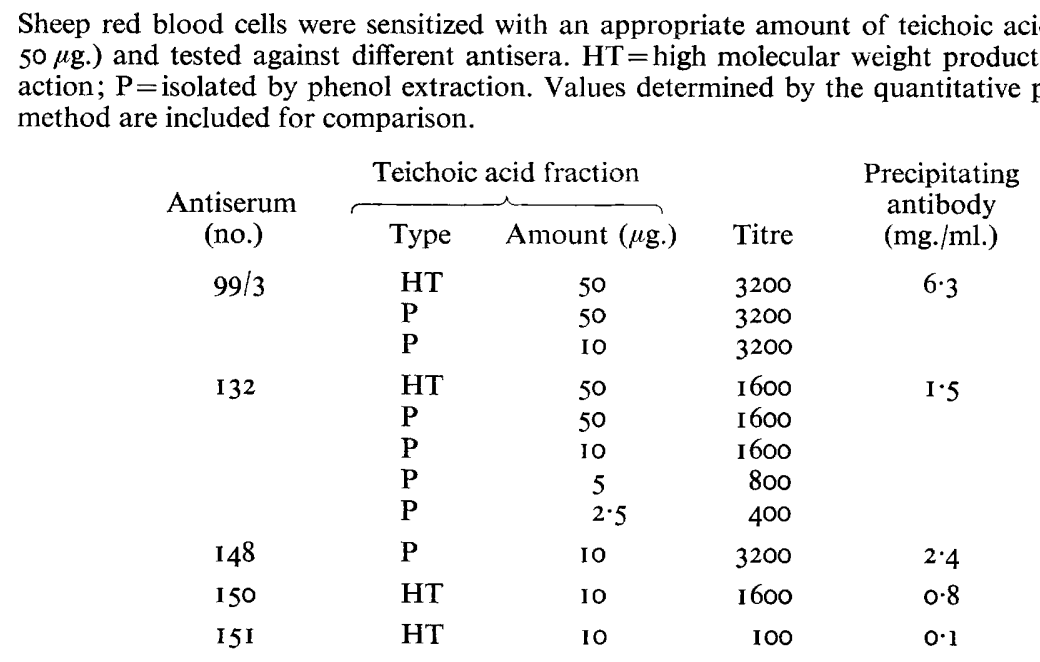

greater variation (Knox et al. 1970). The specificity of haemagglutination was shown by the lack of agglutination in the absence of teichoic acid, and the complete inhibition of agglutination on prior incubation of the serial dilutions of antiserum with HTteichoic acid (Io $\mu \mathrm{g}$.); LT-teichoic acid ( $20 \mu \mathrm{g}$.) caused a partial inhibition, the titre in the reaction between antiserum I48 and P-teichoic acid decreasing from 3200 to 400.

It was previously shown that aqueous ammonia degraded HT-teichoic acid with the release of fatty acids and a decreased serological reactivity (Knox et al. 1970). It has now been shown that HT-teichoic acid subjected to these conditions partially lost its 
ability to sensitize erythrocytes. The titre of antiserum 148 with erythrocytes sensitized by Io $\mu \mathrm{g}$. HT-teichoic acid was 3200 ; with Io $\mu \mathrm{g}$. degraded teichoic acid the apparent titre was 800 .

\section{Inhibition of haemagglutination by bacterial cells}

A washed suspension (I I mg. dry wt/ml.) of Lactobacillus fermenti NCTC 699I was prepared from a $24 \mathrm{hr}$ culture. Suspensions of bacteria $(0.25$ to $2 \mathrm{ml}$.) were centrifuged and $2 \mathrm{ml}$. of dilute serum ( $\mathrm{I} \mathrm{ml}$. diluted to $\mathrm{I} 2.5 \mathrm{ml}$. with $0.85 \% \mathrm{NaCl}$ ) added to the pellet; the antisera examined were $99 / 3$ and I48. After shaking and then standing for I 5 min. at $37^{\circ}$ the bacteria were deposited by centrifugation, and the antiserum tested by the haemagglutination procedure, using erythrocytes sensitized with P-teichoic acid ( $10 \mu \mathrm{g} . / \mathrm{ml}$.). In each case I $\mathrm{ml}$. bacterial suspension decreased the titre from 3200 to I00; continued incubation of antisera and bacterial cells for $2 \mathrm{hr}$ at $37^{\circ}$ and overnight at 2 to $4^{\circ}$ did not decrease the titre further. The decrease in titre related to the dry weight of organisms used, being 400 with $0.25 \mathrm{ml}$. of suspension and $<50$ with $2 \mathrm{ml}$. suspension.

There was no detectable decrease in titre when antiserum ( $2 \mathrm{ml}$. of 50 -fold dilution) was shaken with cell walls (Io mg.) from strain NCTC 699 I.

\section{Estimation of proportion of membrane teichoic acid of intact organisms reacting with antibodies}

Determinations were made of the teichoic acid content of disintegrated organisms by the quantitative precipitin method. After disintegration for $20 \mathrm{~min}$. very few organisms stained Gram-positive but release of cell constituents was not complete even after $35 \mathrm{~min}$. disintegration. Expressed as a percentage of bacterial dry weight the amount of teichoic acid estimated after $35 \mathrm{~min}$. was $1.0 \%$ for the $100,000 \mathrm{~g}$ residue and $\mathrm{I} \cdot 55 \%$ for the supernatant solution (Fig. I). The results are expressed in terms of the reactivity of P-teichoic acid with antisera. It is probable that teichoic acid in disintegrated cells is associated with protein; however, from estimates of the protein content of the bacterial extracts (Folin-Ciocalteu method) the error resulting from expressing all the protein in the antigen-antibody precipitate as antibody protein would not account for more than $0.1 \%$ teichoic acid. The observation (Fig. I) that the major proportion of the teichoic acid is not deposited with the membrane fraction at $100,000 \mathrm{~g}$ may be attributed either to the fragility of the protoplast membrane (cf. Shockman \& Slade, 1964) or to the presence of a labile attachment of lipoteichoic acid to membrane.

Assuming that the total teichoic acid content of the cell membrane represented $2.5 \%$ of the cell mass before disintegration, a calculation may be made of the proportion of the teichoic acid of intact cells reacting with antibody. From the results reported in the previous section. I I $\mathrm{mg}$. of bacteria of strain NCTC 699 I lowered the titre of antiserum I 48 from 3200 to IOO, or almost complete absorption. From previous studies by the quantitative precipitin method (Knox et al. 1970), the amount of precipitating antibody in the antiserum was $380 \mu \mathrm{g}$., which was sufficient to precipitate $15 \mu \mathrm{g}$. of P-teichoic acid. From the results in Fig. I the total amount of teichoic acid in I I mg. bacteria is $275 \mu \mathrm{g}$. If it is assumed that precipitation of antibody can be equated with absorption of antibody then the results indicated that only $5.5 \%$ of the teichoic acid content of whole cells was reactive. A comparable estimation for antiserum 99 showed 


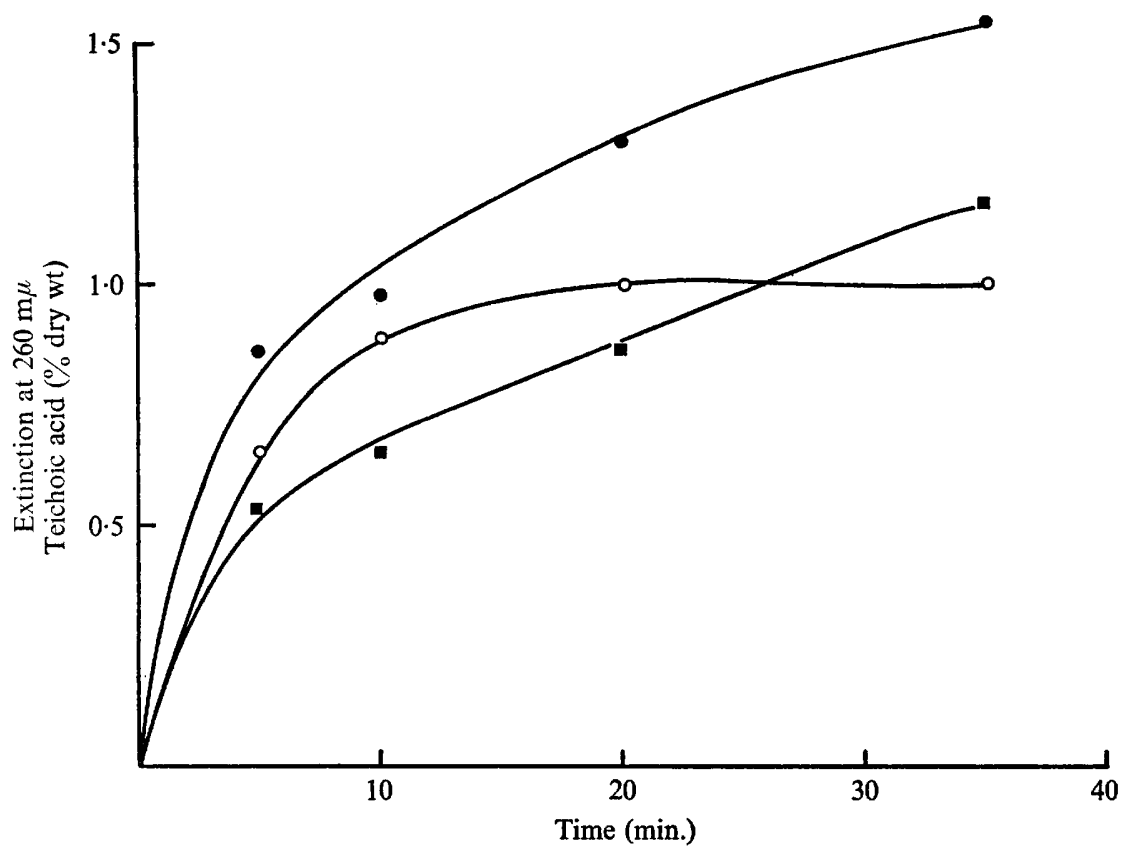

Fig. I. Release of u.v.-absorbing material ( $\boldsymbol{\square})$ and teichoic acid on disintegration of organisms; the teichoic acid was separated into the fraction sedimented at $100,000 \mathrm{~g}(\mathrm{O})$ and the fraction remaining in the supernatant solution (•). Absorption at $260 \mathrm{~m} \mu$ was measured on the whole extract. The teichoic acid content of the extracts was estimated serologically (using P-teichoic acid as standard) and the results are expressed in terms of per cent of the dry wt of bacteria from which the extracts were obtained.

Table 2. Effect of absorption of antiserum with bacteria on the haemagglutination titre

Comparable amounts of bacteria of each strain were shaken with $2 \mathrm{ml}$. of diluted antiserum 148. The titre of the serum before absorption was 3200 and the table records the values after absorption; two concentrations of serum were tested: (a) I ml. diluted to $12.5 \mathrm{ml}$. and (b) I ml. diluted to $50 \mathrm{ml}$.

Serological
group
A
B
C
D
E
F

$\begin{array}{ll}\begin{array}{c}\text { Species of } \\ \text { Lactobacillus }\end{array} & \text { Strain } \\ \text { helveticus } & 8025 \\ \text { casei } & \text { H 83I } \\ \text { casei } & \text { R O94 } \\ \text { casei } & 6375 \\ \text { plantarum } & 7220 \\ \text { bulgaricus } & \text { B 9 } \\ \text { lactis } & 7278 \\ \text { fermenti } & 699 \text { I } \\ & 77 \\ & \text { I26 }\end{array}$

$\begin{array}{rr}{ }_{(a)} & \text { Titre } \\ 3200 & 800 \\ 3200 & \mathrm{I} 600 \\ 3200 & \mathrm{I} 600 \\ 3200 & \mathrm{I} 600 \\ 1600 & 400 \\ 800 & 200 \\ 800 & 800 \\ I 00 & <200 \\ 1600 & 800 \\ 1600 & 800\end{array}$


that I I mg. of bacteria lowered the titre from 3200 to 100 , though in this case the amount of precipitating antibody was $\mathrm{I} \cdot 0 \mathrm{mg}$. This was sufficient to react with $40 \mu \mathrm{g}$. teichoic acid or $14.5 \%$ of that present in the intact organisms.

\section{Cross-reactions with other strains of lactobacilli}

The ability of other strains of lactobacilli to absorb antibodies to P-teichoic acid was investigated by the procedure used above for NCTC 699I. Laboratory strains of Lactobacillus fermenti were examined, and also representative strains of each of the other serological groups. The suspensions of these bacteria were adjusted so as to contain a bacterial concentration similar to that used for $L$. fermenti NCTC 699I. To detect weak cross-reactions, the bacteria were shaken with two dilutions of antiserum $148,(a)$ I $\mathrm{ml}$. diluted to $12.5 \mathrm{ml}$. and $(b) \mathrm{r} \mathrm{ml}$. diluted to $50 \mathrm{ml}$. The results showed that other strains of $L$. fermenti only partially absorbed antibodies to strain NCTC 699I (Table 2). Organisms from groups A, D and E absorbed a significant amount of antibody from the more dilute serum. Cell wall (Io mg.) from L. plantarum NCIB 7220 also absorbed antibodies, the titre of the more dilute serum decreasing to 800 . A number of the strains was tested against other antisera but no significant variations in reaction were observed.

\section{DISCUSSION}

The observation that lipoteichoic acid (P- or HT-teichoic acid) from Lactobacillus fermenti NCTC 699I can be absorbed to normal sheep red blood cells enabled the application of haemagglutination to a study of teichoic acid antigens. LT-teichoic acid, the low molecular weight product of TCA action, is devoid of lipid and is not able to sensitize erythrocytes for haemagglutination, though it does cause a partial inhibition of haemagglutination of erythrocytes sensitized by lipoteichoic acid. The lack of reactivity of LT-teichoic acid and the loss of activity of HT-teichoic acid under conditions which remove fatty acids probably relate to the role of the lipid component in sensitizing erythrocytes. The fatty acid content of the lipoteichoic acids ( 4 to $5 \%$ as palmitic acid) is similar to that found to be effective in rendering polysaccharides capable of absorbing to erythrocytes. Hämmerling \& Westphal (1967) first demonstrated this effect when they showed that the addition of $5 \% O$-stearoyl groups to a number of polysaccharides gave optimal erythrocyte-sensitizing properties. Application of the procedure to streptococcal group-specific polysaccharides was studied in detail by Slade \& Hämmerling (1968), and the present results for the amount of antigen required to sensitize erythrocytes and the resultant titres are comparable to those reported by these investigators.

Although lipid has not previously been reported as occurring in association with teichoic acids, the studies of several groups of workers on a common erythrocytesensitizing antigen occurring in a variety of Gram-positive organisms is consistent with its being a lipoteichoic acid. This antigen, first detected in phenol extracts of organisms by Rantz, Randall \& Zuckerman (1956), is an intracellular glycerol teichoic acid with D-alanine substituents (Gorzynski, Neter \& Cohen, 1960; Stewart, 196r; Jackson \& Moskowitz, I966). Jackson \& Moskowitz (1966) concluded that alanine was responsible for the attachment of antigen to red blood cells, though the conditions used in the experiments that led to this conclusion would also have removed fatty acids 
Further, the ability of alanine-free P-teichoic acid from Lactobacillus fermenti to absorb on to erythrocytes is indicative that alanine is not required for sensitization.

Antibodies to the lipoteichoic acid of Lactobacillus fermenti were absorbed completely from diluted serum on standing with apparently intact organisms for $15 \mathrm{~min}$. Cell wall did not absorb antibodies nor did the cell-wall polysaccharide react with antibodies to purified teichoic acid (Knox et al. 1970). It may, therefore, be concluded that absorption of antibodies implies their penetration of the cell wall to react with membrane teichoic acid. However, the quantitative studies indicate that only a small proportion of the membrane teichoic acid of intact organisms is apparently able to react with antibody, suggesting that access of antibody to the membrane teichoic acid is a limiting factor. The absorption by intact group $\mathrm{D}$ streptococci of antibodies to the group antigen also implies penetration of the wall by antibody, as investigations by a number of workers (see Shockman \& Slade, 1964) have led to the conclusion that the antigen is associated with the membrane.

Of the other strains of lactobacilli that were examined, those in groups A, D and E absorb a significant amount of antibody from antisera to lipoteichoic acid from Lactobacillus fermenti NCTC 699I. The reactions by strains of groups A and E may relate to the presence of glucosyl-glycerol teichoic acids as cell-wall components, with strain B9, which is the most effective, also containing galactose (Sharpe et al. 1964). A cross-reaction with glucosyl-ribitol teichoic acid of group D cell wall would be considered less likely but is suggested by the ability of purified cell wall to absorb antibodies.

This work was supported by a grant (to K. W. K.) from the National Health and Medical Research Council of Australia.

\section{REFERENCES}

Gorzynski, E. A., Neter, E. \& Cohen, E. (I960). Effect of lysozyme on the release of erythrocytemodifying antigen from staphylococci and Micrococcus lysodeikticus. Journal of Bacteriology 8o, 207.

Hämmerling, U. \& WeStPhal, O. (1967). Synthesis and use of $O$-stearoyl polysaccharides in passive hemagglutination and hemolysis. European Journal of Biochemistry $\mathbf{1}, 46$.

Heidelberger, M. \& MacPherson, C. F. C. (I943). Quantitative microestimation of antibodies in the sera of man and other animals. Science, New York 97, 405.

HoFsTAD, T. (1965). Studies on the antigenic structure of the 80/8I complex of Staphylococcus aureus. 4. Antigenic properties and chemical basis of serological reactivity of a purified polysaccharide. Acta Pathologica et Microbiologica Scandinavica 63, 422 .

JACKSON, R. W. \& Moskowitz, M. (I966). Nature of a red cell sensitizing substance from streptococci. Journal of Bacteriology 91, 2205.

Knox, K. W., Hewett, M. J. \& WiCKen, A. J. (I970). Studies on the group F antigen of lactobacilli: Antigenicity and serological specificity of teichoic acid preparations. Journal of General Microbiology 60, 303.

Knox, K. W. \& Holmwood, K. J. (1968). Structure of the cell wall of lactobacilli. Role of muramic acid phosphate in Lactobacillus fermenti. Biochemical Journal 108, 363 .

Rantz, L. A., Randall, E. \& ZuCKerman, A. (I956). Hemolysis and hemagglutination by normal and immune serums of erythrocytes treated with a nonspecies specific bacterial substance. Journal of Infectious Diseases $\mathbf{9 8 ,} 2 \mathrm{I} 1$.

Sharpe, M. E. (1955). Serological classification of lactobacilli. Journal of General Microbiology I2, 107 . 
Sharpe, M. E., Davison, A. L. \& Baddiley, J. (1964). Teichoic acids and group antigens of lactobacilli. Journal of General Microbiology 34, 333.

Shockman, G. D., Kole, J. J. \& Toennies, G. (I957). A high-speed shaker for the disruption of cells at low temperature. Biochimica et Biophysica Acta 24, 203.

Shockman, G. D. \& SLA.DE, H. D. (1964). The cellular location of the streptococcal group D antigen. Journal of General Microbiology 37, 297.

Slade, H. D. \& Hämmerling, U. (1968). Detection by hemagglutination of antibodies to group A and group $\mathrm{E}$ streptococci by the use of $\boldsymbol{O}$-stearoyl derivatives of their cell wall carbohydrategrouping antigens. Journal of Bacteriology 95, 1572.

STEWART, F. S. (I96I). Bacterial polyglycerophosphate. Nature, London 190, 464.

WiCKEN, A. J. \& KNOX, K. W. (1970). Studies on the group F antigen of lactobacilli: Isolation of a teichoic acid-lipid complex from Lactobacillus fermenti NCTC 6991. Journal of General Microbiology 6o, 293.

YosHIDA, K. \& EKSTEDT, R. D. (I968). Antibody response to Staphylococcus aureus in rabbits: sequence of immunoglobulin synthesis and its correlation with passive protection in mice. Journal of Bacteriology 96, I54.0. 